\title{
Coating with chitosan film of sea bream (Sparus aurata) fillets: determining shelf life in refrigerator conditions
}

\author{
Levent İZCİ ${ }^{1 *}$, Furkan EKİCİ², Ali GÜNLÜ3
}

\begin{abstract}
In the investigate, we objectived to assess the effect of coating with chitosan film on the shelf life. To this end, skinless sea bream fillets were separated as control group (C), vacuum packed (VP) and coated with chitosan film and vacuum packed $(\mathrm{CF}+\mathrm{VP})$. Samples of each group were periodically analyzed for microbiological [Total mesophilic aerobic count (TMAc) and Total psychrophilic aerobic count (TPAc)] and physicochemical $[\mathrm{pH}$, Total volatile basic nitrogen (TVB-N), Thiobarbituric acid (TBA) and Trimethylamine nitrogen (TMA-N)] in storage time. It was determined that CF+VP had the highest shelf life among the sample groups. The findings of the study showed that covering sea bream fillets with chitosan film and vacuum packaging significantly prolongs the consumption of the sea bream fillets.
\end{abstract}

Keywords: sea bream; chitosan; film coating; shelf life.

Practical Application: The effect on quality properties of coating with chitosan film of fish fillets.

\section{Introduction}

Sea bream (Sparus aurata) is an important for aquaculture in Turkey. The species is highly demanded both in Turkey and Europe. According to the Turkish Statistical Institute (TÜİ) in 2015 the amount of sea bream aquaculture in Turkey was 51,844 tons. Sea bream is delivered to the domestic and foreign markets both as fresh chilled and frozen (Turkish Statistical Institute, 2015).

Fish is a type of perishable food and it loses its freshness and quality very quickly after death. Loss of freshness and deterioration is a complicated process. A variety of factors, such as different storage conditions and fish species differences affect deterioration in some way (Zaragozá et al., 2013).

There is a different process for the protection of the food, but a suitable package is necessary as the final phase of the protection. Hence, packaging of food quality is important (Debeaufort et al., 1998).

Edible films can be described as a thin polymer layer not only providing gas and moisture barrier for food but can also be consumed with food. Apart from their barrier properties, They can be used as a carrier matrix for antimicrobial and antioxidant substances (Torlak \& Nizamlıoğlu, 2011). They are preferred for their properties such as being not toxic, low priced, biodegradability, biocompatibility, their aesthetic appearance and barrier properties (Vásconez et al., 2009). At the same time, they are used to extend the shelf life of foods owing to these properties (Vásconez et al., 2009; Günlü \& Koyun 2013).

Chitosan is a polyaminosaccaride obtained by the alkaline deasetilation of chitin (Yuexia et al., 2011). Due to its wide range of food applications, chitosan is defined as a versatile biopolymer.
Chitosan can be derived as chitin from some fungal cell walls and shells of arthropods such as lobster, shrimp and crab. Chitosan's applicability in foods is due to their biocompatibility and nontoxicity (Jeon et al., 2002).

Several investigates have been done to determine the shelf life of Sparus aurata (Kyrana et al., 1997; Tejada \& Huidobro 2002; Grigorakis et al., 2003; Chouliara et al., 2005; Cakli et al., 2007; Erkan, 2007; Özogul et al., 2007; Kılınc et al., 2007).

No resource is unlimited in the world, so it is important that the resulting product should have a long shelf life, and be healthy and high quality. In this research, we objectived to assess the effect of coating with chitosan film on the shelf life.

\section{Materials and methods}

\subsection{Materials}

Sea bream (Sparus aurata) was supplied from the fish market (Isparta/TURKEY). In this study, a total of 20 sea bream samples between 300-350 g weight were used. First, heads and viscera were removed immediately and skinless fillets were prepared. Commercially chitosan (Sigma C3646, $\geq 75 \%$ deacetylated, USA) obtained from crab shell was used for chitosan film preparation.

\subsection{Prepapration of chitosan films}

Chitosan films were created based on the method of Günlü \& Koyun (2013). For the production of chitosan films, chitosan $(2 \%, \mathrm{w} / \mathrm{v})$ was added into glacial acetic acid $(1 \%, \mathrm{v} / \mathrm{v})$ and the mixture was mixed for 1 hour with magnetic stirrer in 
$40^{\circ} \mathrm{C}$ (Wisestir MSH 20A, Korea). Then, 2\% (v/v) glycerol was added slowly to the mixture as plasticizer and mixed again with heater magnetic stirrer for $10 \mathrm{~min}$ and the foam was removed with vacuum pump (KNF Neuberger, Germany). $100 \mathrm{~mL}$ of resulting homogeneous mixture was poured on the styrofoam plates $(10 \mathrm{~cm} \times 20 \mathrm{~cm})$ to cover the surface and air dried in $45^{\circ} \mathrm{C}$ in drying oven (Labart, DHG $9140 \mathrm{~A}$, Korea) for 24 hours to prepare chitosan-based edible films.

\subsection{Samples groups and storage}

Three groups were formed from skinless fillets. Group 1; samples were packed in under atmospheric conditions bags and were used as control (C). Group 2 contained only vacuum packed (VP) samples. Group 3, samples were coated with chitosan film and vacuum packed $(\mathrm{CF}+\mathrm{VP})$. All sample groups were stored in a refrigerator $\left(4 \pm 1{ }^{\circ} \mathrm{C}\right)$.

\subsection{Microbiological analysis}

The microbiological analyses of each sample group were carried out under aseptic conditions. $10 \mathrm{~g}$ sea bream flesh was added in sterile bag together with $90 \mathrm{~mL}$ of sterile peptone water and was homogenized with stomacher for 90 seconds (BagMixer 400, France). TMAc and TPAc were found with the pour plate method (Harrigan \& McCance, 1976; Arslan et al., 1997). TMAc and TPAc were found using plate count agar respectively at $30^{\circ} \mathrm{C}$ for 3 days and $4{ }^{\circ} \mathrm{C}$ for 10 days incubation. The results of the samples were given as $\log \mathrm{cfu} / \mathrm{g}$.

\section{$2.5 \mathrm{pH}$ analysis}

For $\mathrm{pH}$ analysis, Fish flesh was homogenized with pure water $(1 / 10)$ then measurement was carried out by $\mathrm{pH}$ meter (Hanna HI 221, Romania) (Varlık et al., 2007).

\subsection{TVB-N analysis}

TVB-N values were determined according to Nicholas (2003) with a small modification. For TVB-N, $25 \mathrm{~g}$ fish sample was homogenized with blender for 30 seconds (Waring Blender, USA) at high speed together with $50 \mathrm{~mL} \mathrm{7.5 \%} \mathrm{trichloroacetic}$ acid (TCA). Homogenizer was filtered with the help of vacuum machine (KNF Neuberger, Germany) and the resulting filtrate was distillated (Velp Scientifica UDK 142, Italy). The resulting distillates were titrated with $0.1 \mathrm{~N} \mathrm{HCl}$. TVB-N value of each $100 \mathrm{~g}$ muscle sample was measured as $\mathrm{mg} / 100 \mathrm{~g}$.

\subsection{TBA analysis}

TBA value was measured by the method Erkan \& Özden (2008), and Erkan et al. (2009). For TBA, $100 \mu \mathrm{l} 0.1 \%$ BHT (Butylated hydroxytoluene) (1 g/ L in ethanol) and $25 \mathrm{~mL} 5 \% \mathrm{TCA}$ was added to $2 \mathrm{~g}$ fish sample and mixtured for 2 minutes at high speed (Heidolph Diax 900, Germany). The resulting homogenizer was filtered. The filtrate was taken to $2 \mathrm{~mL}$ tube, then $2 \mathrm{~mL}$ freshly prepared TBA reagent (Malondialdehyde bis-diethy acetal) was added. Tightly closed tubes were kept in a water bath for 30 minutes at $95^{\circ} \mathrm{C}$ (Memmert WB 22, Germany). After cooling the tubes, the absorbance values of the samples were determined at $532 \mathrm{~nm}$ against blind thorough spectrophotometer (T80 + UV/VIS Spectrometer, PG) and from the regression curve equation for the standard samples, the TBA value of the samples were obtained as malondialdehyde in milligrams/kilogram (mg MDA/kg).

\subsection{TMA-N anaylsis}

TMA-N value was measured according to AOAC (Association of Offical Analytical Chemists, 1998). $90 \mathrm{~mL}$ 7.5\% of TCA was added on $10 \mathrm{~g}$ fish flesh and homogenized and filtered. The filtrate was fixed with $20 \%$ formaldehyde. $4 \mathrm{~mL}$ filtrate was added to glass tube and $1 \mathrm{~mL}$ formaldehyde, $10 \mathrm{~mL}$ anhydrous toluene and $3 \mathrm{~mL} \mathrm{~K}_{2} \mathrm{CO}_{3}$ solution were added. Tubes were shaken and $5 \mathrm{~mL}$ were taken to another tube with pipette in toluene phase and $5 \mathrm{~mL}$ picric acid $(0.02 \%)$ was added and mixed and at $410 \mathrm{~nm}$ spectrophotometer (T80 UV/VIS Spectrometer, PG) the absorbance values were measured against the blind. The TMA-N value was obtained from the resulting standarts curve and measured $(\mathrm{mg} / 100 \mathrm{~g})$.

\subsection{Statistical analysis}

The resulted data in this study were analyzed by means of Analysis Variance (one-way ANOVA) by SPSS 9.0 software. Averages of significant variance resources were then compared using Duncan Multiple Comparison Test with $P<0.05$.

\section{Results and discussion}

\subsection{Assesment of microbiological analysis}

Microbiological analysis is one of the important parameters that need to be taken into consideration in determining the quality of the product. TMAc and TPAc of C, VP and CF + VP sample groups obtained during the cold storage have been reported in Figures 1 and 2. The initial TMAc and TPAC values were respectively $4.15 \log \mathrm{cfu} / \mathrm{g}$ and $4.05 \mathrm{log} \mathrm{cfu} / \mathrm{g}$. As a result, the number of bacteria in all groups increased

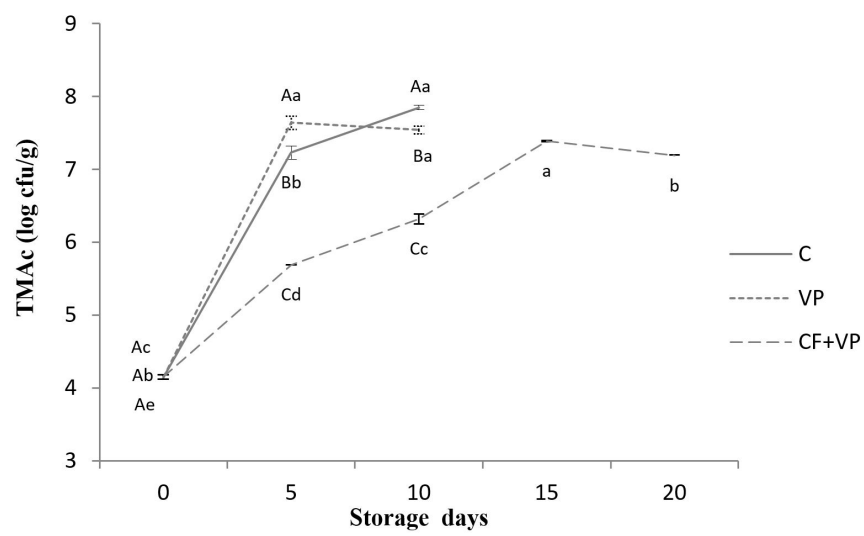

Figure 1. TMAc changes of S.aurata fillets during storage at $4 \pm 1^{\circ} \mathrm{C}$, control group (C), vacuum packed (VP) and chitosan film coated and vacuum packed $(\mathrm{CF}+\mathrm{VP})$ samples. While different lowercase letters define significant $(P<0.05)$ differences between each group for the during storage, different uppercase letters define the group differences $(P<0.05)$ on the same day. 


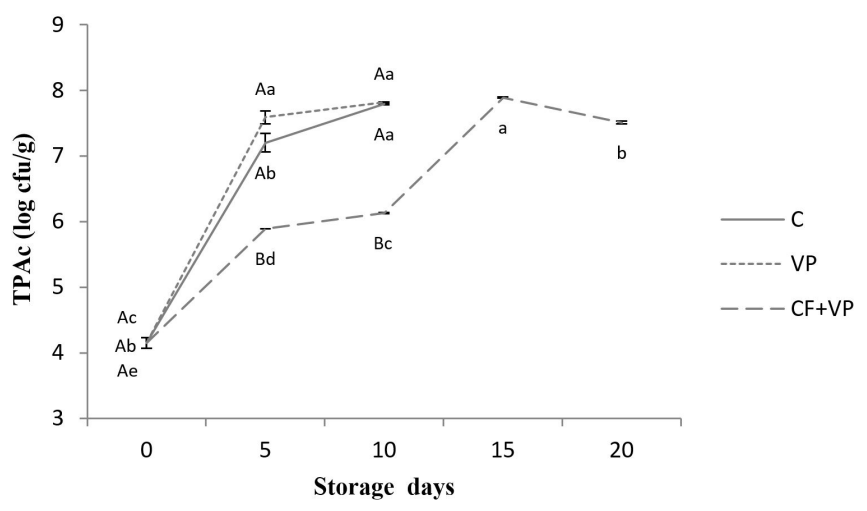

Figure 2. TPAc changes of $S$. aurata fillets during storage at $4 \pm 1{ }^{\circ} \mathrm{C}$, control group (C), vacuum packed (VP) and chitosan film coated and vacuum packed $(\mathrm{CF}+\mathrm{VP})$ samples. While different lowercase letters define significant $(P<0.05)$ differences between each group for the during storage, different uppercase letters define the group differences $(P<0.05)$ on the same day.

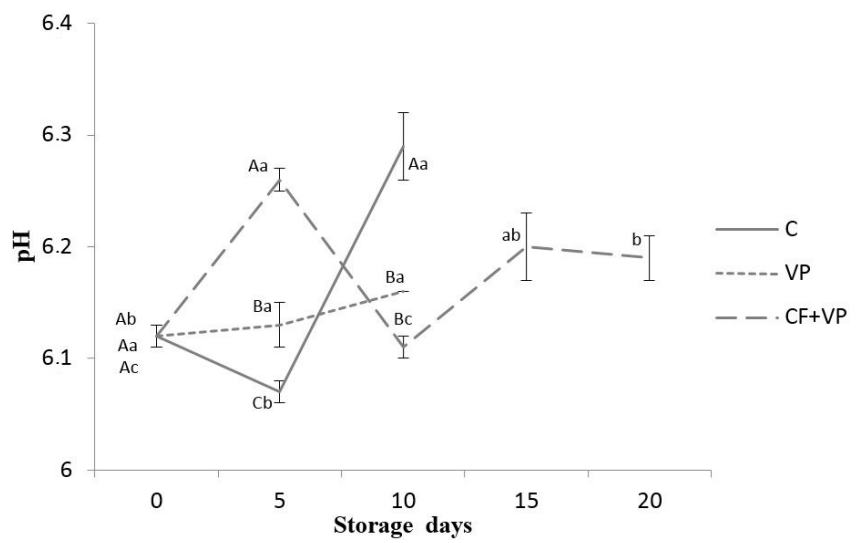

Figure 3. $\mathrm{pH}$ changes of $S$. aurata fillets during storage at $4 \pm 1{ }^{\circ} \mathrm{C}$, control group (C), vacuum packed (VP) and chitosan film coated and vacuum packed $(\mathrm{CF}+\mathrm{VP})$ samples. While different lowercase letters define significant $(P<0.05)$ differences between each group for the during storage, different uppercase letters define the group differences $(P<0.05)$ on the same day.

during storage. Limit value for aerobic bacteria count has been reported as $7 \mathrm{log} \mathrm{cfu} / \mathrm{g}$ (International Commission on Microbiological Specifications for Foods, 1986). In this study the limit value was exceeded in C and VP group samples on storage day $5^{\text {th }}$ while in CF+VP group samples it was surpassed on the $15^{\text {th }}$ day. Jeon et al. (2002) indicated that, following the storage in the refrigerator for 12 days, microorganism development in chitosan coated cod and herring fillets was less significant than those not coated. Souza et al. (2010) showed that, total aerobic plate count of chitosan film coated salmon fillets did not reach limits ( $15^{\text {th }}$ day), but the salmon fillets without any coating reached to $7.05 \mathrm{log} \mathrm{cfu} / \mathrm{g}$ on the $12^{\text {nd }}$ day and exceeded the limit level $(7 \log \mathrm{cfu} / \mathrm{g})$. They proved that coating with chitosan boosted the shelf life of the salmon for 3 days. In another study on silver carp, Fan et al. (2009) stated that in samples coated with chitosan and frozen for 30 days $\left(-3{ }^{\circ} \mathrm{C}\right)$ the total bacteria did not exceed the limit level (7 log cfu/g). Lopez-Caballero et al. (2005) expressed

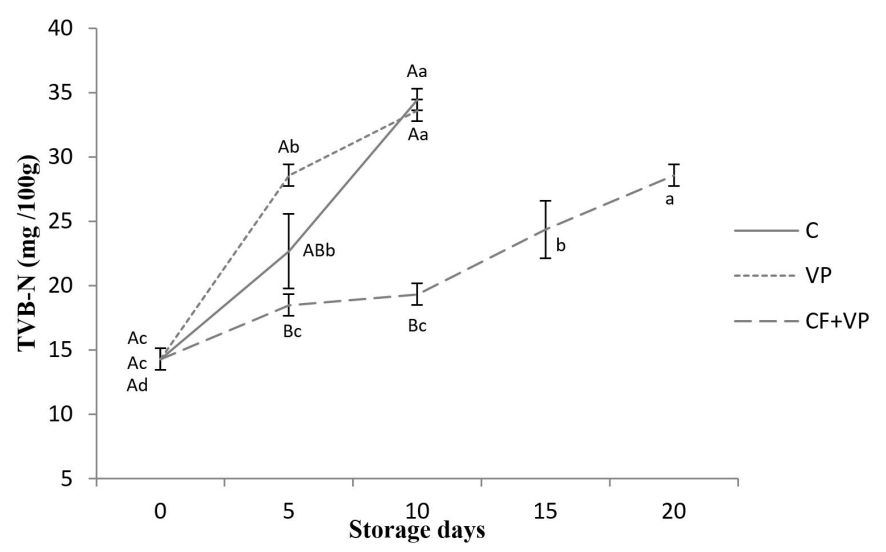

Figure 4. TVB-N changes of $S$. aurata fillets during storage at $4 \pm 1{ }^{\circ} \mathrm{C}$, control group (C), vacuum packed (VP) and chitosan film coated and vacuum packed $(\mathrm{CF}+\mathrm{VP})$ samples. While different lowercase letters define significant $(P<0.05)$ differences between each group for the during storage, different uppercase letters define the group differences $(P<0.05)$ on the same day.

that, in fish patties prepared using cod fillets, coating with a blend of gelatin-chitosan limits the microbial development and approximately $2 \log$ cycle differences arises between the control group and coated group for the level of total bacterial count. Following the storage at for 2 weeks of lingcod fish fillets, Duan et al. (2010) expressed that, while total plate count in the uncoated samples were a total of $7.55 \mathrm{log} \mathrm{cfu} / \mathrm{g}$, it was below $10^{7} \mathrm{cfu} / \mathrm{g}$ in the chitosan coated samples. Vásconez et al. (2009) coated sliced salmon fillet with chitosan and chitosan-tapioca starch and found that total growth of mesophilic and psychrophilic microorganisms were more limited during the storage period only in chitosan coated samples. Similarly, some other researchers reported chitosan's antimicrobial effect (Zhou et al., 2011; Alak et al., 2010).

\subsection{Assesment of physicochemical analysis}

$\mathrm{pH}$ changes of the sample groups were given on Figure 3. Initially, $\mathrm{pH}$ was measured at 6.12 . The $\mathrm{pH}$ values of all the sample groups fluctuated during storage. Similar results were reported by Doğan \& İzci (2017), in a study where hot smoked Oncorhynchus mykiss fillets were coated with chitosan and stored at $4 \pm 1{ }^{\circ} \mathrm{C}$, and by Günlü \& Koyun (2013) using vacuum packed and chitosan film coated Dicentrarchus labrax fillets.

The TVB-N is very commonly used in the determination of spoilage of seafood (Ruiz-Capillas \& Moral, 2001). Huss (1988) reported that acceptable TVB-N limit values are $30-35 \mathrm{mg} / 100 \mathrm{~g}$. At the beginning, TVB-N value was found as $14.28 \mathrm{mg} / 100 \mathrm{~g}$. Similar results were reported by different researchers studying who studied on ice stored S. aurata (Tejada \& Huidobro, 2002; Grigorakis et al., 2003; Kılınc et al., 2007). Günlü \& Koyun (2013) stated that TVB-N increased with during the storage $\left(4^{\circ} \mathrm{C}\right)$ in control, vacuuming, chitosan covering and vacuuming $D$. labrax fillet samples. In our study, the TVB-N value increased in all sample groups in relation to time with storage period (Figure 4). The minimum TVB-N value in all of the samples was found in $\mathrm{CF}+\mathrm{VP}$ samples. These results advised that coating 


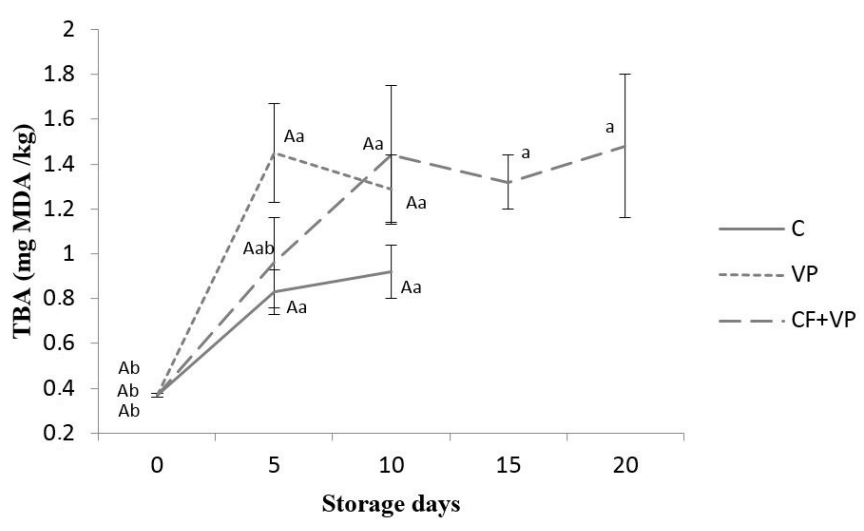

Figure 5. TBA changes of $S$. aurata fillets during storage at $4 \pm 1{ }^{\circ} \mathrm{C}$, control group (C), vacuum packed (VP) and chitosan film coated and vacuum packed $(\mathrm{CF}+\mathrm{VP})$ samples. While different lowercase letters define significant $(P<0.05)$ differences between each group for the during storage, different uppercase letters define the group differences $(P<0.05)$ on the same day.

with chitosan may effect on delaying the increase of the TVB-N value. Similar results were also reported by different researchers (Fan et al., 2009; Gómez-Estaca et al., 2010; Ojagh et al., 2010; Alak et al., 2010; Li et al., 2013).

Lipid oxidation is an important issue for quality of food. It causes oxidative rancidity in fat containing foods. TBA is one of the important indicators of oxidative rancidity (Özogul et al., 2005). TBA value of the fish flesh over 3-4 mg MDA/kg is an accepted indicator of quality loss (Köse et al., 2001). Schormüller (1968) stated a consumability limit value of TBA as $8 \mathrm{mg} \mathrm{MDA} / \mathrm{kg}$. In the study, at first the TBA was determined $0.37 \mathrm{mg} \mathrm{MDA} / \mathrm{kg}$. The limit value was not exceeded in all sample groups during storage (Figure 5). Kyrana et al. (1997) stated that TBA level was 0.67 $\mathrm{mg} \mathrm{MDA} / \mathrm{kg}$ at the beginning of the storage of iced gilthead sea bream in the refrigerator and reached to $1.07 \mathrm{mg} \mathrm{MDA} / \mathrm{kg} 24$ days later. Cakli et al. (2007) stated that at first TBA value of the ice stored S. aurata and D. labrax respectively as $0.360 \mathrm{mg} \mathrm{MDA} / \mathrm{kg}$ and $0.259 \mathrm{mg} \mathrm{MDA} / \mathrm{kg}$. These values increased on the $18^{\text {th }}$ storage day up to $0.949 \mathrm{mg} \mathrm{MDA} / \mathrm{kg}$ and $1.415 \mathrm{mg}$ MDA/kg. K1lınc et al. (2007) reported the initial TBA value of the slurry ice and flake ice stored sea bream respectively as $0.51 \mathrm{mg} \mathrm{MDA} / \mathrm{kg}$ and $0.65 \mathrm{mg} \mathrm{MDA} / \mathrm{kg}$, and these values increased on the $15^{\text {th }}$ storage day up to $2.19 \mathrm{mg} \mathrm{MDA} / \mathrm{kg}$ and $3.00 \mathrm{mg} \mathrm{MDA} / \mathrm{kg}$. Mohan et al. (2012) coated Indian oil sardine (Sardinella longiceps) fillets (double style) with $1 \%$ and $2 \%$ chitosan solution and by storing in ice examined the quality changes. Researchers initially identified the TBA for all samples as $0.32 \mathrm{mg} \mathrm{MDA} / \mathrm{kg}$ and at the end of the 11 day storage time, the TBA value of the samples coated with $1 \%$ chitosan solution was $2.65 \mathrm{mg} \mathrm{MDA} / \mathrm{kg}$ and with $2 \%$ chitosan solution $2.41 \mathrm{mg} \mathrm{MDA} / \mathrm{kg}$. Sathivel (2005) also stated that chitosan coating ( $1 \%$ and $2 \%$ chitosan solution) was effective in decreasing lipid oxidation.

TMA is occured by the bacterial degradation and decomposition of TMAO owing to enzymatic activity (Cakli et al., 2007). Huss (1988) specified the limit value for TMA-N as $10-15 \mathrm{mg} / 100 \mathrm{~g}$. TMA-N levels of the study groups were reported on Figure 6.

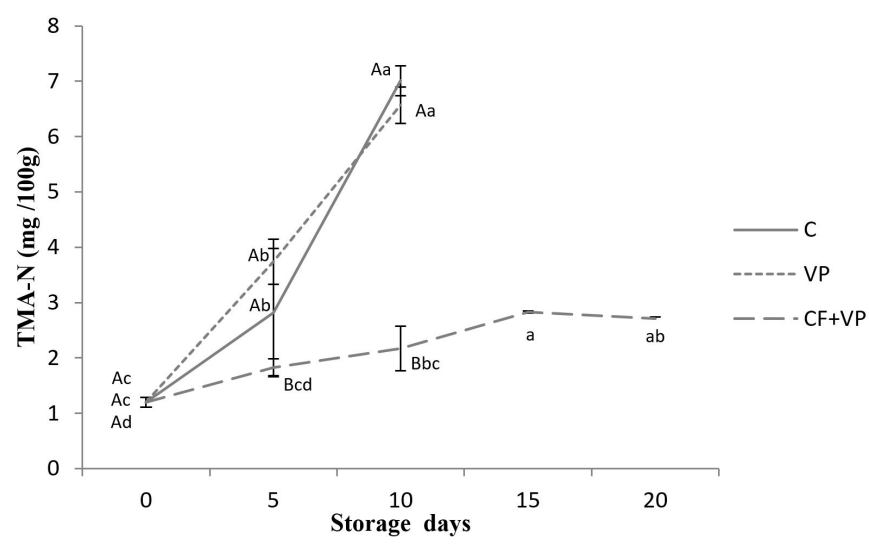

Figure 6. TMA-N changes of $S$. aurata fillets during storage at $4 \pm 1{ }^{\circ} \mathrm{C}$, control group (C), vacuum packed (VP) and chitosan film coated and vacuum packed $(\mathrm{CF}+\mathrm{VP})$ samples. While different lowercase letters define significant $(P<0.05)$ differences between each group for the during storage, different uppercase letters define the group differences $(P<0.05)$ on the same day.

Initally, TMA-N value was $1.20 \mathrm{mg} / 100 \mathrm{~g}$. Although it increased in relation to the time period in all the groups, the TMA-N level did not exceed the limit in any of the groups in the sample storage time. Similar results were showed for $S$. aurata stored in ice by different researchers (Cakli et al., 2007; Erkan, 2007). Günlü \& Koyun (2013) stated that the increase of TMA-N value in the chitosan film coated and vacuumed D. labrax samples were smaller scale when compared to the uncoated samples. Other researchers also reported that chitosan coating process of fish restricts the increase in TMA (Jeon et al., 2002; Nicholas, 2003; Alak et al., 2011; Mohan et al., 2012).

\section{Conclusion}

In this study, shelf life of sea bream fillets coating with chitosan film and vacuuming was extended. The analysis results showed that the physicochemical values did not exceed the limit in all of the groups. Spoilage in all of the groups was determined with microbiological results. While in C and VP samples, limit values were exceeded on the $5^{\text {th }}$ storage day, in CF+VP samples this happened on the $15^{\text {th }}$ day. Therefore, as a result of this study, it can be suggested that the shelf life of perishable products such as seafood could be remarkably improved by the use of natural biopolymer such as chitosan.

\section{Acknowledgements}

We thanks to The Scientific and Technological Research Council of Turkey (TUBITAK 2209/A) for its financial support.

\section{References}

Alak, G., Aras Hisar, S., Hisar, O., Kaban, G., \& Kaya, M. (2010). Microbiological and chemical properties of bonito fish (Sarda sarda) fillets packaged with chitosan film, modified atmosphere and vacuum. Kafkas Üniversitesi Veteriner Fakültesi Dergisi, 16(Suppl A), 73-80. http://dx.doi.org/10.9775/kvfd.2009.1475. 
Alak, G., Hisar, Ş. A., Hisar, O., \& Genççelep, H. (2011). Biogenic amines formation in Atlantic bonito (Sarda sarda) fillets packaged with modified atmosphere and vacuum, wrapped in chitosan and cling film at $4{ }^{\circ} \mathrm{C}$. European Food Research and Technology, 232(1), 23-28. http://dx.doi.org/10.1007/s00217-010-1354-z.

Arslan, A., Çelik, C., Gönülalan, Z., Ateş, G., Kök, F., \& Kaya, A. (1997). Analysis of microbiological and chemical qualities of vacuumed and unvacuumed mirror carp (Cyprinus carpio L.) pastrami. Turkish Journal of Veterinary and Animal Sciences, 21, 23-29.

Association of Offical Analytical Chemists - AOAC. (1998). Offical methods 971.14, Trimethylamine nitrogen in seafood colorimetric method (chap. 35, pp. 7). Gaithersburg: MD.

Cakli, S., Kilinc, B., Cadun, A., Dincer, T., \& Tolasa, S. (2007). Quality differences of whole ungutted sea bream (Sparus aurata) and sea bass (Dicentrarchus labrax) while stored in ice. Food Control, 18(5), 391-397. http://dx.doi.org/10.1016/j.foodcont.2005.11.005.

Chouliara, I., Savvaidis, I. N., Riganakos, K., \& Kontominas, M. G. (2005). Shelf-life extension of vacuum-packaged sea bream (Sparus aurata) fillets by combined $\gamma$-irradiation and refrigeration: microbiological, chemical and sensory changes. Journal of the Science of Food and Agriculture, 85(5), 779-784. http://dx.doi.org/10.1002/jsfa.2021.

Debeaufort, F., Quezada-Gallo, J.-A., \& Voilley, A. (1998). Edible Films and Coatings: Tomorrow's Packagings: A Review. Critical Reviews in Food Science and Nutrition, 38(4), 299-313. PMid:9626488. http:// dx.doi.org/10.1080/10408699891274219.

Doğan, G., \& İzci, L. (2017). Effects on quality properties of smoked rainbow trout (Oncorhynchus mykiss) fillets of chitosan films enriched with essential oils. Journal of Food Processing and Preservation. 41(1), 1-12. http://dx.doi.org/10.1111/jfpp.12757.

Duan, J., Cherian, G., \& Zhao, Y. (2010). Quality enhancement in fresh and frozen lingcod (Ophiodon elongates) fillets by employment of fish oil incorporated chitosan coatings. Food Chemistry, 119(2), 524-532. http://dx.doi.org/10.1016/j.foodchem.2009.06.055.

Erkan, E. (2007). Sensory, chemical, and microbiological attributes of sea bream (Sparus aurata): effect of washing and ice storage. International Journal of Food Properties, 10(3), 421-434. http:// dx.doi.org/10.1080/10942910600848915.

Erkan, N., \& Özden, Ö. (2008). Quality assessment of whole and gutted sardines (Sardina pilchardus) stored in ice. International Journal of Food Science \& Technology, 43(9), 1549-1559. http://dx.doi. org/10.1111/j.1365-2621.2007.01579.x.

Erkan, N., Tosun, Ş. Y., Alakavuk, D. Ü., \& Ulusoy, Ş. (2009). Keeping quality of different packaged salted Atlantic bonito "Lakerda". Journal of Food Biochemistry, 33(5), 728-744. http://dx.doi.org/10.1111/j.17454514.2009.00247.x.

Fan, W., Sun, J., Chen, Y., Qiu, J., Zhang, Y., \& Chi, Y. (2009). Effects of chitosan coating on quality and shelf life of silver carp during frozen storage. Food Chemistry, 115(1), 66-70. http://dx.doi.org/10.1016/j. foodchem.2008.11.060.

Gómez-Estaca, J., López De Lacey, A., López-Caballero, M. E., GómezGuillén, M. C., \& Montero, P. (2010). Biodegradable gelatin-chitosan films incorporated with essential oils as antimicrobial agents for fish preservation. Food Microbiology, 27(7), 889-896. PMid:20688230. http://dx.doi.org/10.1016/j.fm.2010.05.012.

Grigorakis, K., Taylor, K. D. A., \& Alexis, M. N. (2003). Seasonal patterns of spoilage of ice-stored cultured gilthead sea bream (Sparus aurata). Food Chemistry, 81(2), 263-268. http://dx.doi.org/10.1016/ S0308-8146(02)00421-1.

Günlü, A., \& Koyun, E. (2013). Effects of vacuum packaging and wrapping with chitosan-based edible film on the extension of the shelf life of sea bass (Dicentrarchus labrax) fillets in cold storage (4 $\left.{ }^{\circ} \mathrm{C}\right)$. Food and Bioprocess Technology, 6(7), 1713-1719. http://dx.doi. org/10.1007/s11947-012-0833-6.

Harrigan, W. F., \& McCance, M. E. (1976). Laboratory methods in food and dairy microbiolgy. London: Academic Press.

Huss, H. H. (1988). Fresh fish-quality and quality changes (FAO Fisheries Series, Vol. 29). Rome: FAO.

International Commission on Microbiological Specifications for Foods - ICMSF. (1986). Microorganism in foods 2 (2nd ed.). Toronto: ICMSF.

Jeon, Y.-J., Kamil, J. Y. V. A., \& Shahidi, F. (2002). Chitosan as an edible invisible film for quality preservation of herring and Atlantic cod. Journal of Agricultural and Food Chemistry, 50(18), 5167-5178. PMid:12188625. http://dx.doi.org/10.1021/jf011693l.

Kılınc, B., Cakl1, S., Cadun, A., Dincer, T., \& Tolasa, S. (2007). Comparison of effects of slurry ice and flake ice pretreatments on the quality of aquacultured sea bream (Sparus aurata) and sea bass (Dicentrarchus labrax) stored at $4{ }^{\circ} \mathrm{C}$. Food Chemistry, 104(4), 1611-1617. http:// dx.doi.org/10.1016/j.foodchem.2007.03.002.

Köse, S., Karaçam, H., Kutlu, S., \& Boran, M. (2001). Investigating the shelf-life of the anchovy dish called 'Hamsikuşu' in frozen storage at $-18 \pm 1{ }^{\circ} \mathrm{C}$. Turkish Journal of Veterinary and Animal Sciences, 25, 651-656. Retrived from http://journals.tubitak.gov.tr/veterinary/ issues/vet-01-25-5/vet-25-5-3-9909-38.pdf

Kyrana, V. R., Lougovois, V. P., \& Valsamis, D. S. (1997). Assesment of shelf-life of maricultured gilthead sea bream (Sparus aurata) stored in ice. International Journal of Food Science \& Technology, 32(4), 339-347. http://dx.doi.org/10.1046/j.1365-2621.1997.00408.x.

Li, T., Li, J., Hu, W., \& Li, X. (2013). Quality enhancement in refrigerated red drum (Sciaenops ocellatus) fillets using chitosan coatings containing natural preservatives. Food Chemistry, 138(2-3), 821-826. PMid:23411183. http://dx.doi.org/10.1016/j.foodchem.2012.11.092.

Lopez-Caballero, M. E., Gómez-Guillén, M. C., Pérez Mateos, M., \& Montero, P. (2005). A chitosan-gelatin blend as a coating for fish patties. Food Hydrocolloids, 19(2), 303-311. http://dx.doi.org/10.1016/j. foodhyd.2004.06.006.

Mohan, C. O., Ravishankar, C. N., Lalitha, K. V., \& Srinivasa Gopal, T. K. (2012). Effect of chitosan edible coating on the quality of double filleted Indian oil sardine (Sardinella longiceps) during chilled storage. Food Hydrocolloids, 26(1), 167-174. http://dx.doi.org/10.1016/j. foodhyd.2011.05.005.

Nicholas, T. A. (2003). Antimicrobial use of native and enzymatically degraded chitosans for seafood aplications (Master's thesis). The University of Maine, Maine.

Ojagh, S. M., Rezaei, M., Razavi, S. H., \& Hosseini, S. M. H. (2010). Effect of chitosan coatings enriched with cinnamon oil on the quality of refrigerated rainbow trout. Food Chemistry, 120(1), 193-198. http://dx.doi.org/10.1016/j.foodchem.2009.10.006.

Özogul, F., Kuley, E., \& Özogul, Y. (2007). Sensory, chemical and microbiological quality parameters in sea bream (Sparus aurata) stored in ice or wrapped in cling film or in aluminium foil at $2 \pm 1$ ${ }^{\circ} \mathrm{C}$. International Journal of Food Science \& Technology, 42(8), 903909. http://dx.doi.org/10.1111/j.1365-2621.2006.01305.x.

Özogul, Y., Özyurt, G., Özogul, F., Kuley, E., \& Polat, A. (2005). Freshness assessment of European eel (Anguilla anguilla) by sensory, chemical and microbiological methods. Food Chemistry, 92, 745-751. http:// dx.doi.org/10.1016/j.foodchem.2004.08.035.

Ruiz-Capillas, C., \& Moral, A. (2001). Correlation between biochemical and sensory qualitiy indices in hake stored in ice. Food Research International, 34(5), 441-447. http://dx.doi.org/10.1016/S09639969(00)00189-7. 
Sathivel, S. (2005). Chitosan and protein coatings affect yield, moisture loss, and lipid oxidation of pink salmon (Oncorhynchus gorbuscha) fillets during frozen storage. Journal of Food Science, 70(8), 455-459. http://dx.doi.org/10.1111/j.1365-2621.2005.tb11514.x.

Schormüller, J. (1968). Handbuch der lebensmittelchemie (Band III/2). New York: Springer Verlag.

Souza, B. W. S., Cerqueıra, M. A., Ruiz, H. A., Martins, J. T., Casariego, A., Teixeira, J. A., \& Vicente, A. A. (2010). Effect of chitosan-based coatings on the shelf life of salmon (Salmo salar). Journal of Agricultural and Food Chemistry, 58(21), 11456-11462. PMid:20936790. http:// dx.doi.org/10.1021/jf102366k.

Tejada, M., \& Huidobro, A. (2002). Quality of farmed gilthead seabream (Sparus aurata) during ice storage related to the slaughter method and gutting. European Food Research and Technology, 215(1), 1-7. http://dx.doi.org/10.1007/s00217-002-0494-1.

Torlak, E., \& Nizamlığlu, M. (2011). Effectiveness of edible chitosan films containing essential oils on Staphylococcus aureus ve Escherichia coli O157:H7. Kafkas Üniversitesi Veteriner Fakültesi Dergisi, 17(Suppl A), 125-129.

Turkish Statistical Institute - TÜİK. (2015). Fishery statistic. Retrived from http://www.tuik.gov.tr/PreTablo.do?alt_id=1005
Varlık, C., Özden, Ö., Erkan, N., \& Alakavuk, D. Ü. (2007). Su Ürünlerinde Temel Kalite Kontrol (No. 4662). İstanbul: İstanbul Üniversitesi Yayin.

Vásconez, M. B., Flores, S. K., Campos, C. A., Alvarado, J., \& Gerschenson, L. N. (2009). Antimicrobial activity and physical properties of chitosan-tapioca starch based edible films and coatings. Food Research International, 42(7), 762-769. http://dx.doi.org/10.1016/j. foodres.2009.02.026.

Yuexia, G., Peng, S., Tao, L., \& Weiping, S. (2011). Synthesis and characterization of carboxymethyl-polyaminate chitosan and its adsorption behavior toward a reactive dye. Carbohydrate Research, 346(6), 769-774. PMid:21349498. http://dx.doi.org/10.1016/j. carres.2010.12.019.

Zaragozá, P., Fuentes, A., Fernández-Segovia, I., Vivancos, J.-L., Rizo, A., Ros-Lis, J. V., Barat, J. M., \& Martínez-Máñez, R. (2013). Evaluation of sea bream (Sparus aurata) shelf life using an optoelectronic nose. Food Chemistry, 138(2-3), 1374-1380. PMid:23411257. http://dx.doi. org/10.1016/j.foodchem.2012.10.114.

Zhou, R., Liu, Y., Xie, J., \& Wang, X. (2011). Effects of combined treatment of electrolysed water and chitosan on the quality attributes and myofibril degradation in farmed obscure puffer fish (Takifugu obscurus) during refrigerated storage. Food Chemistry, 129(4), 16601666. http://dx.doi.org/10.1016/j.foodchem.2011.06.028. 